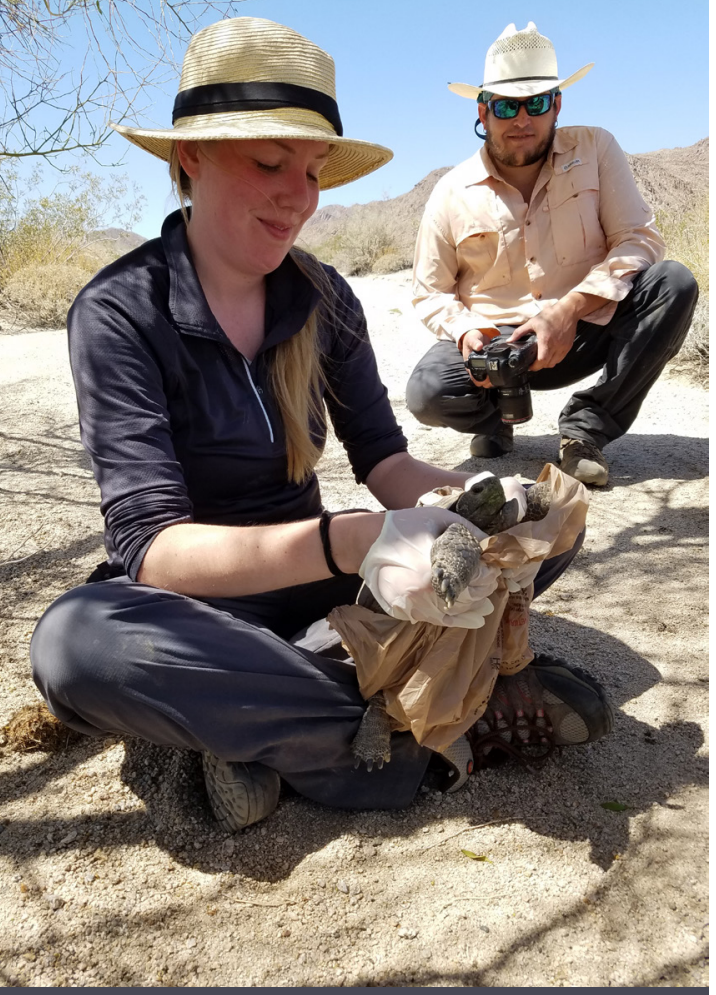

U.S. Geological Survey (USGS) science includes more than just geology! Our research is dedicated to the timely, relevant, and impartial study of the health of our ecosystems and environments, our natural resources, the impacts of climate and landuse change, and the natural hazards that affect our lives. USGS science encompasses, but is not limited to, the following fields:

- Biology and Ecosystems

- Climate Change

- Energy and Minerals

- Environmental Health

- Geology

- Mapping, Remote Sensing, and Geospatial Data

- Natural Hazards

- Planetary Science

- Water

Please note: U.S. citizenship is required for all government positions.

\title{
Student and Recent Graduate Employment Opportunities
}

\section{Employment Opportunities at the USGS}

\section{Are you a current student or recent graduate?}

The USGS hires around 1,000 students and recent graduates each year to fill temporary and entry-level positions to assist with science research and support through various internship programs and opportunities. USGS student and recent graduate positions are publicly advertised year round on the Federal Government's employment Web site USAJOBS and can be viewed at https://www.usajobs. gov/StudentsAndGrads, by selecting either "Find Internships" for students or "Find Recent Graduate Jobs" for graduates within 2 years of receiving a degree. The search results can be refined under "Department and Agency" by selecting "Department of the Interior: Geological Survey." Many of these student and recent graduate positions have the option for conversion to full-time employment. For application tips and more information about USGS opportunities for students and recent graduates, visit http://education.usgs.gov/careers.html.

\section{Are you looking for a another type of} position with the USGS?

In addition to those positions tailored for students and recent graduates, all USGS job openings are advertised through the USAJOBS Web site (https:// www.usajobs.gov/); search results can be refined to target specific positions. Create a profile to set up automatic notification when a position that meets your specifications is announced.

\section{Internships and Fellowships}

\section{NAGT/USGS Cooperative Summer Field Training Program}

Are you a geoscience student participating in summer field camp?

Top students nominated by their field camp director will have the opportunity to apply for a summer internship with the USGS. The USGS partners with the National Association of Geoscience Teachers (NAGT) to provide summer internships for selected students. Established in 1965, this program is one of the longest continuously running science internships in the country. Nominations are solicited in the fall, and students are then invited to apply for summer positions with the USGS doing scientific work in a field, laboratory, or office setting. More than 2,350 students have participated in this program, with many participants continuing on to distinguished careers with the USGS, academia, or industry. For more information, visit http://education.usgs.gov/nagt/ nagtinternship.html.
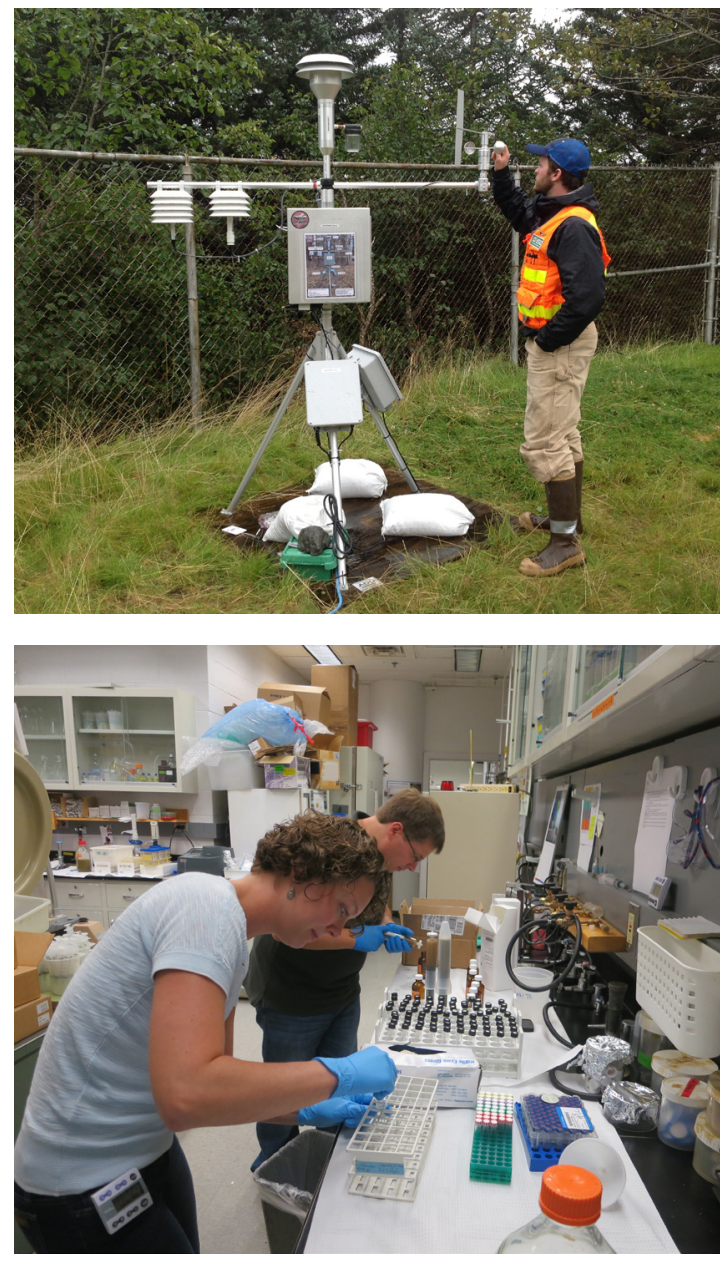


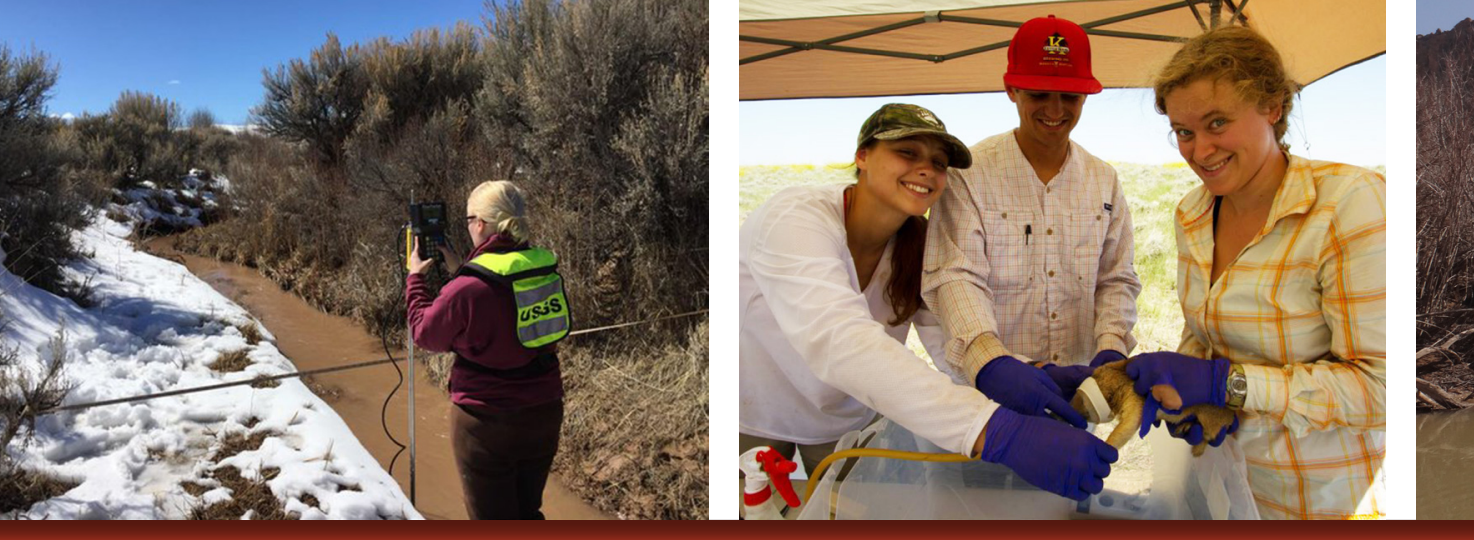

\section{USGS Internship Opportunities for NSF- Supported Graduate Students}

\section{Are you an NSF Graduate Research} Fellow or NSF-funded Ph.D. student?

The National Science Foundation (NSF) has created two opportunities for NSF-supported students to complete internships at the USGS and other Federal agencies. (1) The Graduate Research Internship Program (GRIP) is open only to NSF Graduate Research Fellows.

(2) The Graduate Student Preparedness (GSP) program is open to any Ph.D. student who is supported by an NSF grant. The goal of both programs is to give student researchers the opportunity to work at a Federal science center. Internships can be arranged for 2 to 12 months, with the possibility of an extension of up to an additional 6 months. For current USGS/NSF internship opportunities and application requirements, visit https:// powellcenter.usgs.gov/national-sciencefoundation-graduate-research-internshipprogram-grip.

\section{USGS Mendenhall Research Fellowship Program}

Are you finishing your Ph.D. degree and want to take on the challenge of scientific research at a Federal agency?

This competitive postdoctoral program allows fellows to conduct concentrated research with members of the USGS professional staff, linking current science expertise to the science strategy of the USGS. Research opportunities spanning the wide range of USGS science are advertised on the Mendenhall Research Fellowship Program Web site (http://geology.usgs.gov/postdoc).
Research opportunities may be posted at any time during the year, and positions are filled depending on the availability of funds. Candidates must have successfully completed a Ph.D. within the last 5 years in an area described by the research opportunity before employment begins. Mendenhall Fellows are appointed to the USGS for 2 years.

\section{USGS Partnerships with Universities}

\section{Have you asked your faculty advisor about USGS research opportunities on your campus?}

The USGS maintains close ties to universities throughout the country with several types of collaborative research efforts. In many cases, USGS offices are on or near campus and USGS scientists work closely with faculty. In some cases, USGS scientists are faculty members. Student opportunities include internships, research collaborations, specialized course work, and jobs. Many of these collaborations are forged between faculty and USGS researchers simply by mutual interest. Students are encouraged to ask faculty about opportunities to become involved in these efforts. In addition, there are three nationally integrated collaborative programs addressing fisheries and wildlife, climate science, and water science.

\section{Cooperative Research Units}

The Cooperative Research Unit (CRU) program was established to enhance graduate education with research focused in fisheries and wildlife sciences.
Each unit involves a collaboration between the USGS, a host university, State agencies, and the Wildlife Management Institute. Currently, there are 40 CRUs in 38 States. For more information, visit http://www.coopunits.org/.

\section{Climate Science Centers}

The USGS manages the Department of Interior Climate Science Centers (CSCs). Located at eight public universities, CSCs work in collaboration with additional university partners, Federal research labs, and tribal colleges to provide the science that helps communities and resource managers understand and respond to climate change. Opportunities for students include internships, fellowships, workshops, and training. For more information, visit https://nccwsc.usgs.gov/.

\section{National Institutes for Water Resources}

The National Institutes for Water Resources (NIWR) consists of 54 member Water Resource Research Institutesone in each of the 50 States, 3 territories, and the District of Columbia. NIWR facilitates partnerships between the USGS and local stakeholders and universities that focus on addressing State and regional water problems including science and regulatory issues surrounding water. NIWR has a national internship program and other opportunities for student engagement. For more information and to find the Water Resource Research Institute nearest you, visit http://niwr.info/. 